\title{
Chia Lehnardt
}

\section{Private Militärfirmen und völkerrechtliche Verantwortlichkeit}

Eine Untersuchung aus humanitär-völkerrechtlicher und menschenrechtlicher
Perspektive

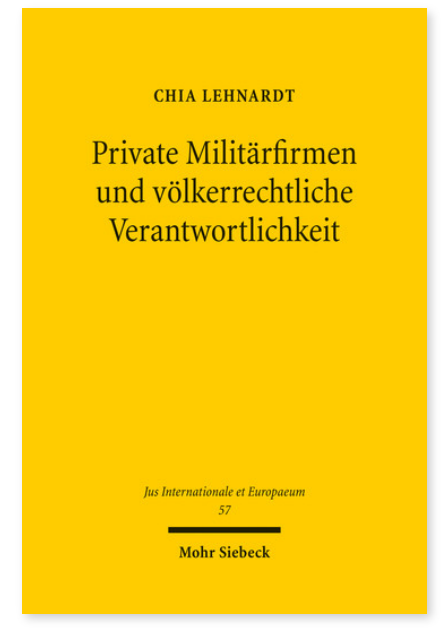

2011. XVII, 299 Seiten. JusIntEu 57

ISBN 978-3-16-151756-3

DOI 10.1628/978-3-16-151756-3

eBook PDF 79,00€

ISBN 978-3-16-150764-9

fadengeheftete Broschur 79,00€
Private Militärfirmen stellen neuartige Herausforderungen an ein Rechtssystem, das sich primär an Staaten und internationale Organisationen richtet. Gleichzeitig ist das hergebrachte Konzept der völkerrechtlichen Verantwortlichkeit zentral für die Verwirklichung humanitär-völkerrechtlicher und menschenrechtlicher Verpflichtungen. Vor diesem Hintergrund untersucht Chia Lehnardt, welche Bedeutung diesem Konzept zukommt, wenn Staaten oder die UN private Militärfirmen einsetzen. Dabei erweist sich das gegenwärtige System völkerrechtlicher Verantwortlichkeit aus zwei Gründen als wirklichkeitsnah. Erstens ist nicht die formale, sondern die tatsächliche Organisation eines Staates bzw. einer Peacekeeping-Operation entscheidend. Zweitens wird die besondere Rolle des Auftraggebers erfasst, indem ihm erhöhte Schutzpflichten auferlegt werden. Mit der Auslagerung militärischer Funktionen geht daher nicht die Auslagerung völkerrechtlicher Verantwortlichkeit einher.

Chia Lehnardt Geboren 1978; Studium der Rechtswissenschaften in Berlin, Oxford und New York; Referendarin am Kammergericht Berlin.
Jetzt bestellen:

https://mohrsiebeck.com/buch/private-militaerfirmen-und-voelkerrechtliche-verantwortlichkeit-9783161517563?no_cache=1 order@mohrsiebeck.com

Telefon: $+49(0) 7071-923-17$

Telefax: +49(0)7071-51104 